www.volsu.ru

DOI: https://doi.org/10.15688/jvolsu3.2017.3.4

UDC 339.5

LBC 65.5

\title{
REGIONAL ECONOMIC INTEGRATION UNDER THE CONDITIONS OF GLOBALIZATION (THE CASE OF THE EURASIAN ECONOMIC UNION (EAEU))
}

\author{
Marina S. Tolstel \\ Lomonosov Moscow State University, Moscow, Russian Federation
}

Elena G. Russkova

Volgograd State University, Volgograd, Russian Federation

Rustam A. Yalmaev

Chechen State University, Grozny, Russian Federation

\begin{abstract}
The process of globalization has significant influence on the national economies. Globalization brings new possibilities as well as new challenges for all actors of the world economy, while the developing supranational associations conduct a more sophisticated economic, social and structural policy, which allows both to offset the negative effects of globalization, and to improve the competitiveness of its members.

The emergence of new international economic integration organizations predetermines the need to rethink the patterns of developing the models of international integration processes, especially in the context of their influence on the economies of member states under the conditions of globalization. The modern economics is not yet able to determine the full effect of the integration processes for member states.

The analysis of the globalization's indices dynamics (the KOF Index of Globalization, the DHL Global Connectedness Index (GCI)) as the indicators of countries' engagement into global economic processes, shows the low level of regional economic integration and the mismatch of economic cycles and payment balance that impose serious constraints to their further development. Economic studies show that the EAEU members do not receive economic benefits from international integration due to many reasons, including the economic and political instability in member states that creates barriers for future prosperity of the EAEU. Using the results of practical research into regional integration problems, the authors analyze the ways to improve the situation and propose their own solutions for the identified problems.

Thus, the aim of our paper is to describe the methodology for estimating the influence of regional integration on the national economies's development under the conditions of globalization (the case of the Eurasian Economic Union (EAEU)); to present current economic situation of countries and to show consequences of their involvement in integration processes for socio-economic development.

Key words: globalization, regional economic integration, economic potential, Eurasian Economic Union (EAEU), economic development, economic growth.

УДК 339.5

ББК 65.5
\end{abstract}

\section{РЕГИОНАЛЬНАЯ ЭКОНОМИЧЕСКАЯ ИНТЕГРАЦИЯ В УСЛОВИЯХ ГЛОБАЛИЗАЦИИ (НА ПРИМЕРЕ ЕВРАЗИЙСКОГО ЭКОНОМИЧЕСКОГО СОЮЗА (ЕАЭС))}

\author{
Марина Сергеевна Толстель
}

Московский государственный университет им. М.В. Ломоносова, г. Москва, Российская Федерация 


\section{Елена Геннадиевна Русскова}

Волгоградский государственный университет, г. Волгоград, Российская Федерация

\section{Рустам Алиевич Ялмаев}

Чеченский государственный университет, г. Грозный, Российская Федерация

Аннотация. Процесс глобализации оказывает существенное влияние на экономическое развитие стран. При этом глобализация приносит как новые возможности, так и вызовы для всех субъектов мировой экономики, в то время как создаваемые наднациональные союзы ведут более сложную экономическую, социальную и структурную политику, которая позволяет как снизить негативное влияние глобализации, так и улучшить конкурентоспособность их участников.

Появление новых международных экономических интеграционных объединений предопределяет необходимость переосмысления закономерностей развития моделей международных экономических интеграционных процессов, особенно в контексте их влияния на экономику стран-участниц в условиях глобализации. Современная экономическая наука пока не способна определить полный эффект для стран-участниц от реализации интеграционных процессов.

Анализ динамики индексов глобализации (KOF Индекса Глобализации, DHL Global Connectedness Index (GCI)) как показателей вовлечения стран в глобальные экономические процессы показывает низкий уровень региональной экономической интеграции и несоответствие экономических циклов платежному балансу, что создает серьезные ограничения дальнейшему их развитию. Экономические исследования показывают, что члены ЕАЭС не получают экономических выгод от международной интеграции по многим причинам, в том числе экономическая и политическая нестабильности в странах-участниках создают барьеры для будущего развития ЕАЭС. Основываясь на результатах практического исследования проблем региональной интеграции, авторы анализируют способы улучшения ситуации и предлагают свои решения выявленных проблем.

Таким образом, целью статьи является описание методологии оценки влияния процессов региональной интеграции на экономическое развитие стран-участниц в условиях глобализации (на примере Евразийского экономического союза (ЕАЭС)), а также оценка текущего уровня их социально-экономического развития и последствий вовлечения в интеграционные процессы.

Ключевые слова: глобализация, региональная экономическая интеграция, экономический потенциал, Евразийский экономический союз (ЕАЭС), экономическое развитие, экономический рост.

There are a lot of theoretical and empirical works that focused on economic effects of international economic integration for member countries and the rest of the world as before (exante) or after (ex-post) their entry. They examines the effect of integration on trade flows and economic growth, the availability of convergence of economic performance between member countries, determine who is the most desirable partner and what form these agreements are most effective and preferred.

The main methods of quantitative analysis, which can be evaluated positive negative effects of integration affecting the country, region, industry in a given country are: computable General and Partial Equilibrium models (CGE) (allow to conduct scenario-based evaluation of integration effects), gravitational econometric model (allow to calculate the impacts of integration, the potential for lack of membership), the intersectional balance model, different indexes (System of Indicators of Eurasian Integration - the SIEI EBD).
As noted in Michalopoulos and Tarr works $[3$, p. 127], the effects associated with growth, it's difficult to describe and even more difficult to measure, this is because, unlike static, dynamic effects are more complex. They arise for a number of reasons, which usually divided into two categories: 1) growth in output due to the growth of factors of production; 2) inducing the growth in total factor productivity due to the acceleration of technological progress. As sources of growth can also be a specialization, economies of scale, the income convergence of member countries, transfer of technology and other factors. All this variety of causes through which integration Association is able to affect growth of the member countries, it's hard to grasp using only one model.

At the same time, the effects of integration associations formation is not limited to the impact on trade flows and production structure $[1 ; 5]$; they can be associated with the growth of investment opportunities, increased competition, 
a deepening of specialization and cooperation, transfer of knowledge and technology migration.

The main value of the estimates of the effects of integration obtained by using Computable General equilibrium models, is not specific values, but in terms of impact on specific economic indicators. Moreover, it shows that among the economic indicators there is a clear relationship and any change in economic policy affects the elements of the economic system [4].

However, in recent years to analyze the consequences of participation in regional trade agreements dynamic General equilibrium models are increasingly used. They have a number of advantages, in particular, better assess the long term effects. At the same time, it's necessary to take into account that the dynamic model is rather complicated and not always possible to achieve acceptable quality.

In the analysis of regional economic relations and an assessment of potential of regional integration there is the System of Indicators of the Eurasian Integration (SIEI) EBD [10] which acts as the instrument of monitoring and an assessment of integration processes in the Former Soviet Union and represents the complex system consisting of the indexes covering various aspects of economic and social integration.

The authors propose a methodology for assessing the impact of multilevel economic integration within the Eurasian Economic Union on the socio-economic development of the participating countries on the basis of integral index, based on the identification, evaluation and prediction of the influence of factors external and internal environment on the changing economic potential of the participants of the integration association.

The basis for the evaluation of factors of economic potential became a set of indicators, divided into five groups and included in the proposed model: 1) the indicators of the factors of production; 2) the indicators of the competitive environment; 3) the indicators for assessing transboundary movement of goods and services (evaluation of external and mutual trade, the analysis of the turnover of the services (the indicators of mutual trade, which characterize quantitative and qualitative parameters of trade flows among countries of the integration group; their impact on economic development; status of the industrial sector of the countries of the EAEU)); 4) the indicators of financial and investment potential; 5) the indicators of social well-being. Estimation of their values is based on the use of the index method to assess the relationship of various elements of the economic system. The calculated indices included in the aggregate model estimates the realization of the EAEU countries economic potential [6, p. 796].

The proposed model is based on the assumption that only systemic development factors and conditions of economic and social activity capable of creating a high level of economic potential development. The development of one of these components will not ensure the achievement of economic synergies in the process of Eurasian integration.

It's important to determine key performance indicators and their target values (given macroeconomic conditions, and synergy of integration association).

The level of EAEU members' economic potential integral indicator (EPR) is calculated as follows:

$$
E P R=\sqrt{\sum_{i=1}^{n} d_{i}\left(1-p_{i}\right)^{2}}
$$

where $p_{i}-$ a normalized value of $i$-indicator; $d_{i}-$ a weighting factor (set by expert on the basis of the influence of this indicator on economic potential integration association member).

Normalized values of indicators influencing the economic potential of the countries participating in the EAEU are calculated by the formulas (2) and (3) for indicators showing respectively the direct effect (the increase in dynamics is considered as a positive trend) and reverse effect (decrease of values in dynamics positive trend):

$$
\begin{gathered}
p_{i}=1-\frac{x}{x_{n}}, \\
i=1-\frac{x_{n}}{x}
\end{gathered}
$$

where $x$ - an actual value of $i$-indicator; $x_{n}-$ a target value of $i$-indicator; $p_{i}$ - a normalized value of $i$ indicator.

Depending on the value of the integral indicator, the authors list the following levels of 
the economic potential of the countries participating in the EAEU:
1) $[1,00-\infty)-$ high;
2) $[0,50-1,00)$ - average;
3) $[0,20-0,50)-$ low;
4) $[0,00-0,20)$ - critical.

The level of economic potential of the EAEU countries is considered to be high in the case where their activities are characterized by stable growth of indicators of the five selected groups, optimal conditions for cross border movement of goods, services and factors of production, high level of openness of national economies of the Eurasian Economic Union, a sufficient degree of financial sources of economy growth.

The average level of the economic potential of the EAEU countries presupposes stable values of the factors of production, competition and social welfare at high trade potential, but also a sufficient degree of availability of financial resources. There is a possibility of increasing the level to high due to creating competitive environment, increasing financial and investment potential. Special attention should be given to improving the indicators of social well-being. Time spent on improving the economic potential of high can be 1-3 years.

Under the low economic potential of the countries participating in the EAEU is defined as the condition in which the values of the indicators of economic potential's factors don't reach their target values. If the value of the integral index is closer to the lower boundary of the interval $[0,20-0,50)$, the potential increase in the level of economic potential is not clear, the upper bound shows the existence of the possibility of its increase to the average level.

The level of economic potential of the countries participating in the EAEU is regarded as critical in the case when the violated treaty, the EAEU values of macroeconomic indicators determining the sustainability of economic development of EAEU member [6, p. 798].

The EAEU is established for the purpose of comprehensive modernization, cooperation and increase of national economies competitiveness and the creation of conditions for stable development in the interests of raising the population living standards through the integration of scientifictechnical, production, labor and financial resources.

First at the institutional level, the distinctive features of the Eurasian integration emerged through the practices of the Customs Union that inspired the creation of a Common market of goods. The EU experience and other economic integration organizations has allowed in the creation of the EAEU (or EurAsEC, the parent structure of integration), the Customs Union and the CES to formulate and apply a number of new methodological solutions, which include:

1) the new model of economic regulation institutions in the integration structures, effectively combining the definition of the interstate goals, supranational forms of decision-making and intergovernmental procedures for their preparation;

2 ) the series-parallel creation of regional economic blocs, i.e. the passage of each next phase of integration coincides with the development and adoption of normative-legal provision of subsequent and previous institutionalization;

3 ) the application of the multi-speed and multilevel integration mechanism, which allows each member, in consultation with partners to shape strategy participation in the integration processes, taking into account the uneven economic development of the EAEU countries, complemented their economic potential [7, p. 31-32].

In addition, a distinctive feature of Eurasian integration is a key role of the Russian Federation as an economically and historically dominant country. The share of Russia accounts for $87,6 \%$ of the economic potential, 78,4\% of the population and $83,9 \%$ of the territory formed the Eurasian Economic Union. In the free trade zone within the CIS Russia accounts for 78,3\% of total GDP, $53,2 \%$ of the population and $79,3 \%$ of the territory. This creates both advantages and difficulties in the EAEU formation [7, p. 30].

As shown by the analysis of the impact of different economic integration levels within the Eurasian economic Union on the socio-economic development of the participating countries, the potential for enhancing the economic effect of integration remains significant [6, p. 797-798]. It will increase due to the growth of mutual trade its share remains significantly lower than in the EU and other regional associations, and through deepening integration, with the creation of the EAEU will cover not only market of goods but also the services market, labour and capital, which requires an appropriate institutional support.

The analysis of the globalization's indexes dynamics (the KOF Index of Globalization, the DHL Global Connectedness Index (GCI)) as the 
country engagement metrics into global economic processes shows that the low level of regional economic integration and the mismatch of economic cycles and balance of payments impose on the process of serious constraints (tab. 1). Economic studies show that the EAEU members do not receive economic benefits from international integration because of many reasons, especially economic and political instability makes barriers for future prosperity of the EAEU.

Table 1 clearly shows that the EAEU member countries were not expected to be the top-ranked country in terms of overall global connectedness. In spite of this fact the Global Connectedness Score of the EAEU member countries is constant over the long-term, over the period 2005-2013 it ranged from 2 to 10 per cent. This current economic marginality is caused by various reasons, such as natural conditions, history, development after USSR (connected with economic instability). Due to various consequences - internal as well as external - since the 2013th economic situation has been improving, this could lead to the growth of the Global Connectedness Score in the future. However, it is necessary to say that the Global Connectedness Rank (out of 140 countries) for all the EAEU members is still very low.

The current KOF Globalization Index reflects the extent of economic, social and political globalization in 2013. According to the Index, the degree of globalization in 2013 increased very little compared to the preceding year. While the Index continued to stagnate in the industrialised countries, Eastern Europe and the Asian and Pacific regions recorded a rise.

What about the EAEU members (fig. 1), the biggest climbers in the overall index in 2013 were Armenia $(+1,87)$, Kyrgyz Republic $(+1,63)$. Substantial setbacks were recorded by Kazakhstan ( -17 ranks).

Table 1

Global Connectedness Index: Values of the EAEU Members Indicators (2005-2013)

\begin{tabular}{|l|c|c|c|c|c|c|c|c|c|}
\hline \multirow{2}{*}{\multicolumn{1}{|c}{ Country }} & \multicolumn{8}{|c|}{ Global Connectedness Score (0-100) } \\
\cline { 2 - 11 } & $\mathbf{2 0 0 5}$ & $\mathbf{2 0 0 6}$ & $\mathbf{2 0 0 7}$ & $\mathbf{2 0 0 8}$ & $\mathbf{2 0 0 9}$ & $\mathbf{2 0 1 0}$ & $\mathbf{2 0 1 1}$ & $\mathbf{2 0 1 2}$ & $\mathbf{2 0 1 3}$ \\
\hline Armenia & 35 & 33 & 35 & 39 & 42 & 43 & 45 & 44 & 44 \\
\hline Belarus & 30 & 30 & 31 & 31 & 32 & 33 & 36 & 36 & 37 \\
\hline Kazakhstan & 48 & 48 & 53 & 52 & 49 & 50 & 52 & 53 & 48 \\
\hline Kyrgyz Republic & 27 & 29 & 29 & 32 & 24 & 22 & 23 & 24 & 26 \\
\hline Russian Federation & 43 & 45 & 41 & 42 & 44 & 44 & 44 & 43 & 44 \\
\hline
\end{tabular}

Source: [2].

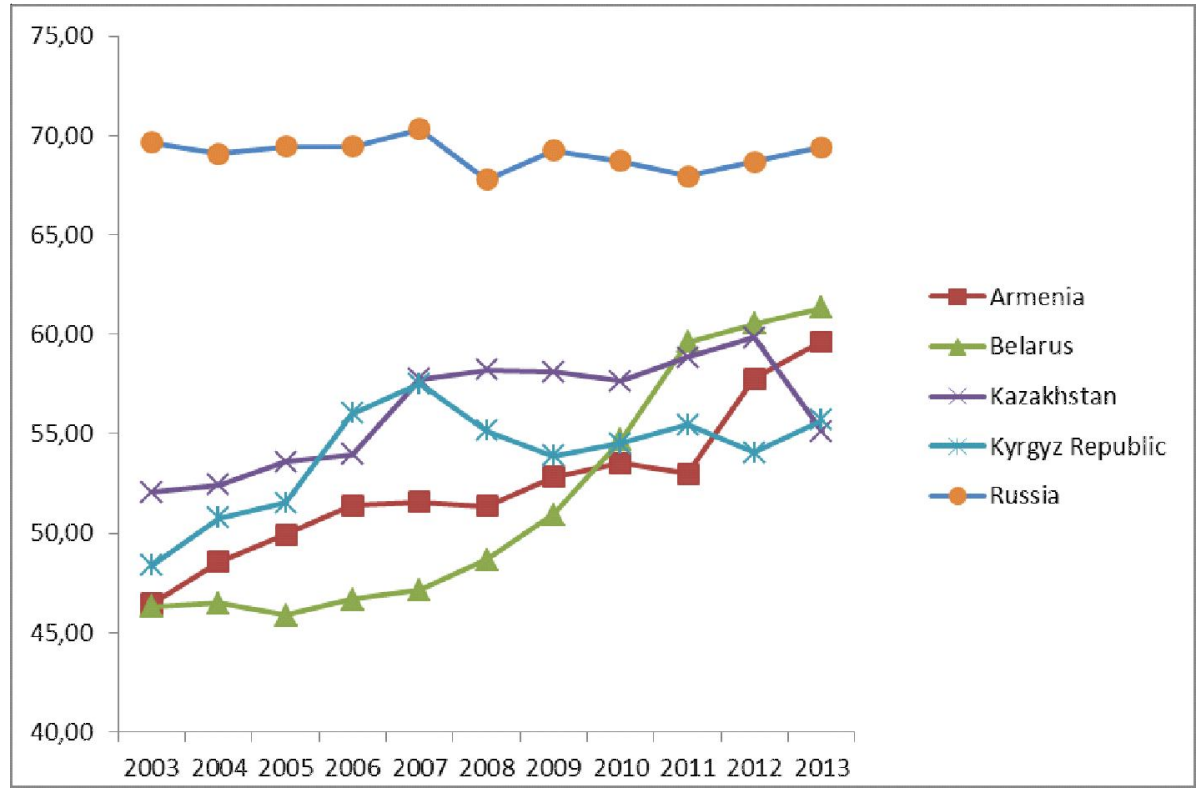

Fig. 1. The KOF Index of Globalization: the EAEU countries' review (period 2003-2013) Source: [9]. 


\section{МЕЖДУНАРОДНЫЕ ИНТЕГРАЦИОННЫЕ ПРОЦЕССЫ}

According to the Index, the Russian degree of globalization increased very little compared to the preceding year. But we expect the index growth in the near future for the EAEU members.

Table 2 shows changes in the positions of The GCI ranking. The situation is similar. According to the Index, the EAEU countries' competitiveness increased very little compared to the preceding year. At the time of writing, the Russian economy continues to face many deeply rooted challenges that will have to be addressed for the country to strengthen its competitiveness. It is reflected not only on the Russian economy, but also on the EAEU economies, instantly depriving them long-term growth potential.

Thus, the level of financial and investment competitiveness of the EAEU countries is not homogeneous, different levels of investment potential development (the acceptable level can be considered the Russian investment resources, provided the redirection to the domestic market or the market of the EAEU partners) that predetermines the need to increase and diversify the sources of investment resources. This requires the accelerated format of the regulatory mechanisms of the common financial market of the EAEU, the development of supplemental incentives to spur domestic investors. It will also contribute to the stabilization and increase of regulation efficiency of the EAEU currency market.

As shown by the analysis of the impact of different economic integration levels within the Eurasian Economic Union on the socio-economic development of the participating countries, the potential for enhancing the economic effect of integration remains significant. It will increase due to the growth of mutual trade - its share remains significantly lower than in the EU and other regional associations, and through deepening integration, with the creation of the EAEU will cover not only market of goods but also the services market, labour and capital, which requires an appropriate institutional support.

The expansion of the economic space greatly increases the potential of existing opportunities, which dramatically enhances the effect of the mentioned factors, differentiating and increasing their variability, this is especially important under the conditions of global instability. Industrial and trade policies of the EAEU countries must meet the basic requirements and principles of national security of each participating countries and integration associations in general. Currently not yet developed a systematic approach to this problem, there is no comprehensive picture of the industrial, trade policies and policies aimed at ensuring national, including economic, security on a consistent basis.

\section{REFERENCES}

1. Blomstrom M., Kokko A. Regional Integration and Foreign Direct Investment: A Conceptual Framework and Three Cases. Policy Research Working Paper 1750. The World Bank, 1997. URL: https://www.researchgate.net/publication/23721980 Regional_Integration_and_Foreign_Direct_ Investment_A_Conceptual_Framework_and_Three_ Cases. (accessed December 12, 2016).

2. Ghemawat P., Altman S.A. DHL Global Connectedness Index 2014. Deutsche Post DHL, November 2014, pp. 11-12. URL: http://www.dhl.com/

Table 2

The Global Competitiveness Index: the EAEU countries' review (period 2007-2016)

\begin{tabular}{|c|c|c|c|c|}
\hline Years & Armenia & Kazakhstan & Kyrgyz Republic & Russia \\
\hline 2007 & 3,866 & 4,256 & 3,379 & 4,134 \\
\hline 2008 & 3,758 & 4,138 & 3,340 & 4,190 \\
\hline 2009 & 3,725 & 4,107 & 3,402 & 4,314 \\
\hline 2010 & 3,711 & 4,076 & 3,360 & 4,153 \\
\hline 2011 & 3,758 & 4,119 & 3,485 & 4,238 \\
\hline 2012 & 3,888 & 4,185 & 3,447 & 4,215 \\
\hline 2013 & 4,022 & 4,376 & 3,436 & 4,197 \\
\hline 2014 & 4,102 & 4,406 & 3,571 & 4,246 \\
\hline 2015 & 4,007 & 4,416 & 3,726 & 4,370 \\
\hline 2016 & 4,010 & 4,485 & 3,835 & 4,439 \\
\hline
\end{tabular}

Source: [8]. 
M.S. Tolstel, E.G. Russkova, R.A. Yalmaev. Regional economic integration under the conditions of globalization

content/dam/Campaigns/gci2014/downloads/ dhl_gci_2014_study_high.pdf(accessed March 15, 2017)

3. Michalopoulos C., Tarr D. The Economics of Customs Unions in the Commonwealth of Independent States. Post-Soviet Geography and Economics, 1997, vol. 38, pp. 125-143.

4. Piermartini R., Teh R. Demystifying modeling methods for trade policy. WTO Discussion Paper, 10. Geneva, World Trade Organization, 2005. URL: https:// www.wto.org/english/res_e/booksp_e/discussion_ papers10_e.pdf. (accessed October 17, 2017).

5. Plummer M., Cheong D., Hamanaka S. Methodology for impact assessment of free trade agreements. Asian Development Bank, 2010. URL: https://aric.adb.org/pdf/FTA_Impact_Assessment. pdf. (accessed December 12, 2016)

6. Pridachuk M., Tolstel M. International Economic Integration: Realities and Perspectives (the case of Eurasian Economic Union (EEU)). Proceedings of International Conference on European Integration 2016. Ostrava, Czech Republic, 2016, pp. 790-799.

7. Tkachuk S. Eurasian Union: on the way to gaining competitiveness. Economic Strategies, 2015, no. 2, pp. 28-41. (in Russian).

8. The Competitiveness Dataset. URL: www3. weforum.org/docs/gsr/2015-2016/GCI_DataSet_20062015.xlsx. (accessed August 2, 2017).

9. The KOF Index of Globalization aggregated graphs. URL: http://globalization.kof.ethz.ch/. (accessed August 2, 2017).

10. Vinokurov E., ed. System of Indicators of Eurasian Integration. Eurasian Development Bank, 2010. URL: https://eabr.org:8888/upload/iblock/ac1/ The-System-of-Indicators-of-Eurasian-Integration. pdf. (accessed October 17, 2017).

\section{Information about the Authors}

Marina S. Tolstel, Candidate of Sciences (Economics), Associate Professor, Senior Researcher, Laboratory of Institutional Issues of Economic Modernization, Lomonosov Moscow State University, GSP-1, Leninskie Gory, 1-46, 119991 Moscow, Russian Federation, marina-tolstel@yandex.ru.

Elena G. Russkova, Doctor of Sciences (Economics), Professor, Director of Institute of World Economy and Finance, Volgograd State University, Prosp. Universitetsky, 100, 400062 Volgograd, Russian Federation, dekan.econom@volsu.ru.

Rustam A. Yalmaev, Candidate of Sciences (Economics), Associate Professor, Head of Department of Regional Economy Management, Chechen State University, Sheripova St., 32, 364093 Grozny, Russian Federation,imamat@list.ru.

\section{Информация об авторах}

Марина Сергеевна Толстель, кандидат экономических наук, доцент, старший научный сотрудник лаборатории институциональных проблем экономической модернизации, Московский государственный университет им. М.В. Ломоносова, ГСП-1, 1-46 Ленинские горы, 119991 г. Москва, Российская Федерация, marina-tolstel@yandex.ru.

Елена Геннадиевна Русскова, доктор экономических наук, профессор, директор института мировой экономики и финансов, Волгоградский государственный университет, просп. Университетский, 100, 400062 г. Волгоград, Российская Федерация, dekan.econom@volsu.ru.

Рустам Алиевич Ялмаев, кандидат экономических наук, доцент, зав. кафедрой управления региональной экономики, Чеченский государственный университет, ул. А. Шерипова, 32, 364093 г. Грозный, Российская Федерация, imamat@list.ru. 